JTE

Journal of Teaching English

Volume 05 No. 04, 2020

e-ISSN: 2548-6810

\title{
EMOTIONAL INTELLIGENCE AND STUDENTS' TRANSLATION ABILITY AT ENGLISH DEPARTMENT OF HALU OLEO UNIVERSITY
}

\author{
Nurfadillah Badarun ${ }^{1}$, Rohmana ${ }^{2}$, Alberth $^{3}$ \\ nurfadillahbadarun@gmail.com \\ ${ }^{1}$ Halu Oleo University, Indonesia
}

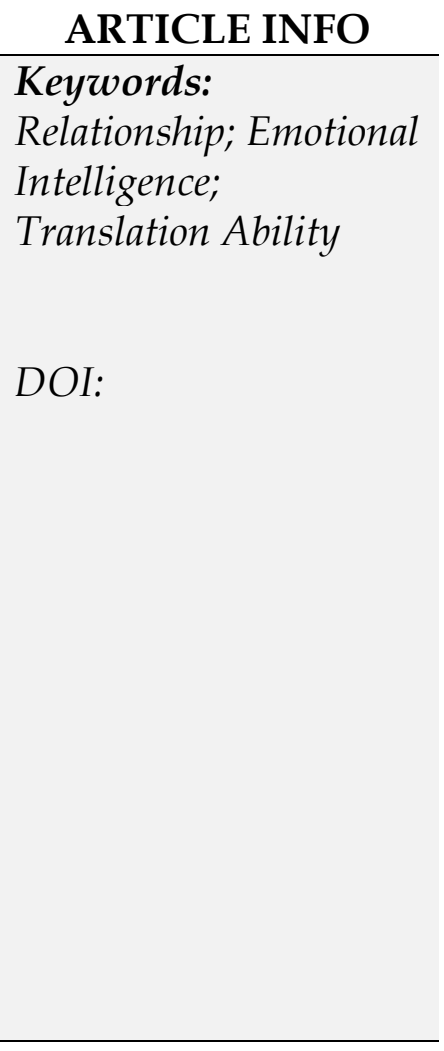

\begin{abstract}
Emotional intelligence and translation ability level vary among individual students. The present study seeks to examine (1) the relationship between students' emotional intelligence and their translation ability. It also aims at (2) determining which dimension of emotional intelligence can best predict students' translation ability. The study employed a descriptive quantitative design. Participants of this study were the sixth semester students in Translation Class at English Education Department of Halu Oleo University. The population was 101 students and 80 students were taken as the sample using purposive sampling technique. The data were obtained from emotional intelligence questionnaire and students' translation scores. The analysis used Pearson correlation and Regression analysis by using SPSS 20. The results reveal that (1) there is no significant relationship between emotional intelligence and students' translation ability, and (2) one of the dimensions of emotional intelligence have statically relationship with students' translation score that is self-regulation dimension.
\end{abstract}

\section{INTRODUCTION}

The fact says that each capacity to learn foreign language tends to be different. According to Hornsby (2005:662) language is a system of sounds or word used by humans to express their thinking and feeling. Among a lot of factors contributing to second or foreign language learning success including motivation or personality types, 
it seems that one significant factor which accounts for success in language learning is the degree of intelligence that individual process (Pisghadam, 2009:1).

One of the recent studies in psychology is the study of Emotional Intelligence (EI), which considered as one of the most important dimensions of intelligence (Murphy, 2006). Emotional Intelligence is a new term and many scholars try to describe and measure it. Considerable studies also show that EI plays a central role in students' academic success, personal and social lives beyond the effects of personality and general intelligence (Jennings \& Greenberg, 2009:1). The importance of Emotional Intelligence exists because emotions drive attention which impact learning, memory, and behaviour (Ohman, Flykt \& Esteves, 2001 in Bracket \& Katulak, 2006).

Emotional intelligence is something that can train and improved with the knowledge. Positive emotions can improve performance, while negative ones can diminish it (Darling-Hammond, et.al n.d, 2014:90). In relation to translation ability, there are many problems to face in translation, these remind us that many aspects are involve it including communication situation, cultural context of source language text, lexicon and grammar (Larson 1984:3). Whatever the problems of translation are, still they have some processes to exchange the meaning of the source language into the target language. In translation, the meaning which exchanged must constant, only the forms change.

Translation is also the other four skills in mastering English language, as well as listening, speaking, reading, and writing, translation is also has major function. A translation process is not as easy as we think. Translation is an activity that increases students' awareness toward similarities and differences between source and target language grammatical structure.

Successful translators have sometimes been described as emotionally engaged individuals (Fraser, 1996:95) who derive personal and contextual meanings from texts (Boase-Beier, 2006:53) and create interpersonal relationships with source text authors and assumed target text readers (Jääskeläinen, 1999:224). Translation ability level and emotional intelligence of each other person is different. Based on that case, the researcher wants to know the relationship between translation ability and emotional intelligence of the sixth semester students of English Department of Halu Oleo University.

The researcher took sixth semester students as a sample because they already joined translation class last semester. So that the researcher correlates the total score of translation class with emotional intelligence of students itself. Based on the background described above, thus the research questions of this research are: "Is there any significant relationship between students' Emotional Intelligence and their translation ability?" and "Which dimension(s) of Emotional Intelligence can best predict students' translation ability?" 


\section{LITERATURE REVIEW}

The concept of Emotional Intelligence is started by Professors Peter Salovey and John D. (Jack) Mayer in 1990. They have conducted very significant research in the area and published many articles. The work of Salovey and Mayer, and the conception of Emotional Intelligence, was made popular by Journalist, Daniel Goleman. According to Daniel Goleman (1995) emotional intelligence as including "abilities such as being able to encourage oneself and tolerate in the face of frustration, to manage desires and delay gratification; to control one's moods and maintain distress from swapping the ability to think; to emphasize and to hope" (1995:34). Later, Goleman recreated his first classification of emotional intelligence and broke down emotional intelligence into twenty-five different emotional competencies, among them self-awareness, service orientation, self-confidence and achievement drive (Goleman, 1998).

In current years, a number of capability models for EI have been developed (Salovey \& Mayer, 1999); the most well known is the model increased by Goleman (1995). In his book "Woring with Emotional Intelligence" has been divided Emotional intelligence into five dimensions such as self-awareness, self-regulation, self-motivation, empathy and social skills. Related to this topic, translation is one of the most main skills that should be learned and developed by the students. Nida and Taber (1968) state that translation consists of replicating in the receptor language to the closest equivalent of the source language message first in term of meaning and secondly in term of style. Translation is no longer just the process of translating words, but evolved into the transformation of meaning and intention.

Based on the definitions above, the researcher concluded that translations included two different languages. They are Source Language and Target Language. According the research by Iwan Supriyatno (2019), a structure shift, or a translation shift in general, can help translators to better translate a text. However, simply changing the structure does not guarantee the accuracy of the translation. In this case, the role of translation is very essential. A translator has to have a proper knowledge about Source Language and Target Language systems.

From the explanations above, there are two key words about translation, that is meaning and equivalence. Meaning in the target text must equal with the meaning in the source text, although it is in different form and structure. In conclusion, translation is a process of replacing messages from one language into another language by finding the equivalence both in meaning and in style without change the meaning of the text.

\subsection{Emotional Intelligence and Translation Ability}

There are several theories and opinions about the relationship between Emotional Intelligence and Translation ability. Translation ability level and emotional intelligence of each other person is different. A combination of these individual differences and characteristics may straight influence their translation quality (Shangarffam \& Abolsaba, 2009; Dongfeng \& Dan, 1999).

According to Farahzad (2003), in psychologically emotions and being intelligent about them are essential factors, and seemingly can manipulate the translation 
activities. Furthermore, In contrast, Robinson (1997) proposed that "translation is an intelligent activity, involving creative problem-solving". It is generally accepted that translation as a problem-solving procedure in which the translator meets problems of different sources and uses tools and resources to solve them. In line with the study by Nilda Iman Syahrani (2019), translation procedures are the way that can be used by the translator to helpthem in translating sentence or a small unit of language in a sentence. These translation procedures can help and make easy the translator in case of translation problem.

Sobhaninejad \& Yoozbashi (2008) stated that makes Emotional Intelligence important is that people with emotional intelligence are able to control their feelings, use their affective data to lead their thoughts and activities which, in turn, link to successful translation and the quality of translation. Furthermore, personal and emotional characteristics are known to cooperate an important role in translation performance (Hubscher-Davidson, 2009).

According to Shangarffam \& Abolsaba (2009), Emotional Intelligence (EI) and Emotional Quotient (EQ level) are among the factors which seem to play an important function in manipulating the translators' mind while translating a text and so contribute to the task of translation. Besides, Emotions and being intelligent about them is an important factor in an individual. It is evident that so many factors involve in the task of translation and translators (Shangarffam \& Abolsaba, 2009).

In Hubscher Davidson's study, self-perceived intuition and emotional traits examine to blow positively on translation performance, suggesting that successful and innovative literary translators might be definitely instinctive and emotionally intelligent. The implication for translation and intelligence is that every translator has different emotional intelligence and translation ability. Many elements of emotional intelligence include the skills translators should have. Emotional intelligence is concern with people and situations. Although words play an important role in translating, people and situations are usually in the translation task. The translator or interpreter seems to play with words. Actually what they do is to cope with people and situations. In doing so, they use words and language as a tool.

According to Pahlavani \& Asroush (2013), the level of Emotional Intelligence might be one of the possible factors manipulating the translators' mind. Besides, the factor is not just emotional of students but many factors have affected the learners' translation ability. No one can deny the role of strong memory, language competence, background knowledge, proficiency level, practical experience, and practice in the success of a translator (Nasimi, 2009).

\section{METHODS}

The main topic of this research is to examine the relationship between Emotional Intelligence and students' translation ability. This study is a correlation research. Descriptive quantitative method was employed to analyze the data by using the SPSS 20. Then, this study described or analyzed which five dimensions of emotional 
intelligence can best predict students' ability in translation; they are self-awareness, selfregulation, self-motivation, empathy and social skill.

Population in this research was all sixth semester students in English Department of Halu Oleo University who joined translation class. The researcher took sixth semester students as population of this study because they already joined translation subject this semester so the score of translation class used as a research instrument. In this study, the researcher used purposive sampling technique. The sixth semester students of translation class at English Department of Halu Oleo University consisted of two classes. Those are class A and B, and the sample of this study is 80 students of two classes.

The questionnaires based on Daniel Goleman's Emotional Intelligence Framework prepare and adopted by The Consortium for Research on Emotional Intelligence; adapted into a questionnaire by Belinda Davies The researcher minimized the questionnaire into five questions in every each dimension of Emotional Intelligence based on students' condition in learning process. To know the students' translation achievement, the researcher used their translation score. The score was found from department's document. The questionnaire was analyzed by using Statistical Package for Social Sciences (SPSS 20). After that, the data of emotional intelligence questionnaire and translation score analyzed with Pearson correlation analysis. To know which dimension of Emotional Intelligence can best predict the students' success in translation ability, Regression analysis with stepwise method were also employed through SPSS statistic software as well. The result of students' emotional intelligence and translation ability score analyzed using Regression analysis through SPSS 20.

\section{FINDINGS AND DISCUSSION}

\subsection{Findings}

The researcher correlates emotional intelligence and translation score using SPSS 20 statistic. The Pearson correlation analysis was conducted to measure the relationship between emotional intelligence and students' translation score. The 80 students of sample were analyzed with their emotional intelligence total score from the questionnaire and the total of students' score translation, here above the data result of analysis two data from SPSS:

\section{Correlations}

\begin{tabular}{|c|c|c|c|}
\hline & & $\begin{array}{c}\text { emotional } \\
\text { intelligence }\end{array}$ & $\begin{array}{c}\text { Translati } \\
\text { on }\end{array}$ \\
\hline Emotional & $\begin{array}{l}\text { Pearson } \\
\text { Correlation }\end{array}$ & 1 & \\
\hline intelligence & Sig. (2-tailed) & & ,265 \\
\hline & $\mathrm{N}$ & 80 & 80 \\
\hline Translation & $\begin{array}{l}\text { Pearson } \\
\text { Correlation }\end{array}$ & , 126 & 1 \\
\hline
\end{tabular}




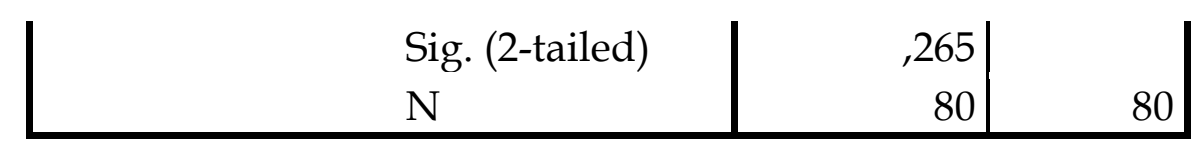

From the table above, it is clear that correlation of two variables; $r=.126$, with $n=80$, suggest that emotional intelligence and students' translation is on negative correlation. The value of sig. alpha $=0,265>0,05$, Sig.alpha is higher than 0,05 , means that emotional intelligence questionnaire score and students' translation score have no significance correlation.

In order to investigate the second research question about which dimensions of emotional intelligence can best predict students' translation, regression linear analysis was carried out.

\section{Coefficients $^{a}$}

\begin{tabular}{|c|c|c|c|c|c|c|}
\hline \multirow{2}{*}{\multicolumn{2}{|c|}{ Model }} & \multicolumn{2}{|c|}{$\begin{array}{l}\text { Unstandardized } \\
\text { Coefficients }\end{array}$} & \multirow{2}{*}{$\begin{array}{c}\text { Standardized } \\
\text { Coefficients }\end{array}$} & \multirow[t]{2}{*}{$\mathrm{T}$} & \multirow[t]{2}{*}{ Sig. } \\
\hline & & B & Std. Error & & & \\
\hline \multirow{6}{*}{1} & (Constant) & 65.181 & 7.825 & & 8.330 & .000 \\
\hline & self awareness & -.139 & .343 & -.052 & -.405 & .687 \\
\hline & self regulation & 1.576 & .518 & .372 & 3.043 & .003 \\
\hline & self motivation & -.452 & .429 & -.146 & -1.053 & .296 \\
\hline & Empathy & .186 & .304 & .079 & .612 & .542 \\
\hline & social skill & .108 & .351 & .043 & .308 & .759 \\
\hline
\end{tabular}

a. Dependent Variable: translation score

From the table above, the data analysis clearly shows that the Sig of other four dimensions of emotional intelligence value is higher than 0.05 while Self-regulation dimension value is lower than 0.05 . Therefore, it can be conclude that one of the dimension of emotional intelligence (self-regulation) have statically relationship with students' translation score.

\subsection{Discussion}

The findings show that there is no relationship between emotional intelligence and students' translation ability. Meanwhile, one of the dimensions of emotional intelligence has statically relationship with translation ability that is self-regulation dimension. The findings of this study revealed that from Pearson-correlation analysis sig alpha is higher than 0,05 (Sig. alpha $=0,265>0,05$ ), it means that there was no significant relationship between the Emotional Intelligence and the students' translation ability. The result of second analysis about dimensions of emotional intelligence that can best predict students translation ability show that one of the five dimensions of emotional intelligence that is self-regulation have statically relationship with students' translation score $(\mathrm{sig}=0.003<0.05)$.

According to Joseph and Newman (2010:69) "persons with high emotion regulation ability make well in jobs that need high emotional labor." According to Goleman (1998), 
self-regulation refers to the skill to handle emotions in carrying out work to make it easier and lack of disrupting the job. Goleman (1998) also implies that those with strong self-regulation skills are high in carefulness. It can be conclude that self-regulation and translation ability have relationship each other because students with self-regulation ability high in carefulness and concentration in translation a text so it can make easier to do their task. In addition, students with self-regulation ability have stable emotion and can handle their emotions well, so it has relationship with their translation ability.

There are some researchers have same finding with this present study. As the result from Samaneh Moghimi, Mandana Yousefi, and Kazem Yousefi (2015), their finding show that there is no any relationship about emotional intelligence and students' translation ability. The previous studies that have same findings with this research also have some different aspects, such as the instrument of emotional intelligence and students' translation ability.

A brief review of the literature indicates that in some studies, translators' Emotional Intelligence was found to affect the quality of the translation product, the process of translating and producing a good translation; while one study did not find a significant relationship between total Emotional Intelligence and translation quality. The researcher supported with relevant finding by Shangarffam and Abolsaba (2009) showed that Emotional Intelligence does not have any relationship with the learners' translation ability. The researcher also said that although the findings of the study show that emotional intelligence does not have any relationship with the quality of translation, their suggest that to train more efficient translators, teachers and professors would better consider the concept of emotional intelligence in their teachings of translation materials. This is, of course, in agreement with the results of the present study.

On the other hand, the results of the present study are opposed to the findings of other researchers such as Mohammad R. Talebinejad (Islamic Azad University, Iran, 2012), Mehrdad Zarafshan (Islamic Azad University, Iran, 2012), who believe that emotional intelligence has a significant relationship with students concerning reading performance, language learning strategies, and reading comprehension.

The contrast finding with this research might be due to employing different methods for assessing emotional intelligence questionnaire and the students' translation ability, different sampling procedures, or different random environmental factors.

In conclusion by concerning on theory, the previous researcher, and the result of this present study, it can be stated that the findings of this research revealed there was no significant relationship between emotional intelligence and the students' translation ability. Besides, the dimensions of emotional intelligence that can best predict students' translation ability show that one of the dimensions of emotional intelligence has statically relationship with students' translation score, that is self-regulation dimension.

\section{CONCLUSION}

Based on the findings of the research and the discussion, there are some conclusions which can be drawn by the researcher. The finding of this study shows that there is no 
significant relationship between emotional intelligence and students' translation in sixth semester students at English Department of Halu Oleo University. The analysis about the dimensions of emotional intelligence that can best predict students' translation ability show that one of the dimensions of emotional intelligence have statically relationship with students' translation score that is self regulation dimension.

Based on the findings of this study and after having some conclusions before, it is advisable to suggest these recommendations to the future researcher. For future studies, the next researcher can conduct another study related to translation and emotional intelligence in order to make a comparison with this research. The next researcher may investigate the effect of students emotional intelligence on students' translation ability. For further research can take other participants to be the material in a different place or location in order to add the data about students' emotional intelligence and students' translation.

\section{References}

Boase-Beier, Jean. (2006). Loosening the grip of the text: Theory as an aid to creativity. In: Manuela Perteghella and Eugenia Loffredo, eds. Translation and Creativity Perspectives on Creative Writing and Translation Studies. London and New York: Continuum, 47-56.

Brackett, M. A., \& Katulak, N. A. (2006). Emotional intelligence in the classroom: Skill-based training for teachers and students. Applying Emotional Intelligence: A Practitioner's guide, 1-27.

Darling-hammond, et.al (n.d). (2014). Feeling Count: Emotions and Learning [a lecture handout].

Farahzad, F. (2003). Sequencing Texts On The Basis Of Difficulty In A Translation Programme. Translation Studies,1(1), 31-44.

Fraser, Janet. (1996). Mapping the process of translation. Meta. 41(1):84-96.

Goleman, D. (1995). Emotional intelligence: Why it can matter more than IQ. New York: Bantam Books.

Goleman, D. (1998). Working with emotional intelligence. New York: Bantam.

Hornsby. (2005). Oxford Advance Learners' Dictionary of Current English. New York: Oxford University Press.

Hubscher-Davidson, Séverine. (2009). Personal diversity and diverse personalities in translation: A study of individual differences. Perspectives: Studies in Translatology. 17(3):175-192.

Jääskeläinen, Riitta. (1999). Tapping the Process: An Explorative Study of the Cognitive and Affective Factors Involved in Translating. Joensuu: University of Joensuu. 
Jennings, P. A., \& Greenberg, M. T. (2009). The Pro-Social Classroom: Teacher Social And Emotional Competence In Relation To Student And Classroom Outcomes. Review of Educational Research, 79(1), 491-525.

Joseph, Dana L. and Newman, Daniel A. (2010). Emotional intelligence: An integrative metaanalysis and cascading model. Journal of Applied Psychology. 95(1):54-78.

Larson, M. A. (1984). Meaning-Based Translation. Lanham: University Press.

Mayer, J. D., \& Salovey, P. (1999). The intelligence of emotional intelligence. Intelligence, 17, 433-442.

Murphy, K. R. (2006). A Critic Of Emotional Intelligence: What Are The Problems And How Can They Be Fixed. New Jersey: Lawrence Erlbaum Association.

Nasimi, A. (2009). The Relationship Between Emotional Intelligence And Learners' Translation Ability In Children Literature (Unpublished Master's Thesis). Iran,Tehran, Islamic Azad University.

Nida, Eugine. A and Taber, Charles. A, 1968. The Theory and Practice translation. E.J Brill: Leiden.

Pahlavani, P., \& Asroush, M. H. (2013). The Relationship between Emotional Intelligence $(E Q)$ and the EFL Learners' Oral Translation Performance.

Pishghadam, R. (2009). A Quantitative Analysis of the Relationship between Emotional Intelligence and Foreign Language Learning. Electronic Journal of Foreign Language Teaching. Vol.6(1), pp.31-41.

Robinson, D. (1997). Becoming a Translator. London and New York: Routledge. http://dx.doi.org/10.4324/9780203441138 chapter 1

Shangarffam, N., \& Abolsaba, A. (2009). The Relationship Between Emotional Intelligence And The Learners' Translation Ability.Journal of Teaching English as a Foreign Language and Literature, 1(2), 103-114.

Sobhaninejad, M., \& Yoozbashi, A. (2008). Emotional intelligence and management in organization. Tehran : Yastaroon Publications.

Supriyatno, I. (2019). The Analysis of Structure Shift in the English Translation of Thesis Abstracts Found at Teacher Training and Education Faculty Halu Oleo University. English Language Education Department, Halu Oleo University.

Syahrani N.I (2019). The Analysis Of Translation Procedures In Subtitle Of "Boychoir" Movie. Journal of Teaching English. Volume 4 No. 3, 2019. English Language Education Department, Halu Oleo University. 